\title{
Modelling the impact of reopening schools in early 2021 in the presence of the new SARS-CoV-2 variant and with roll-out of vaccination against COVID-19
}

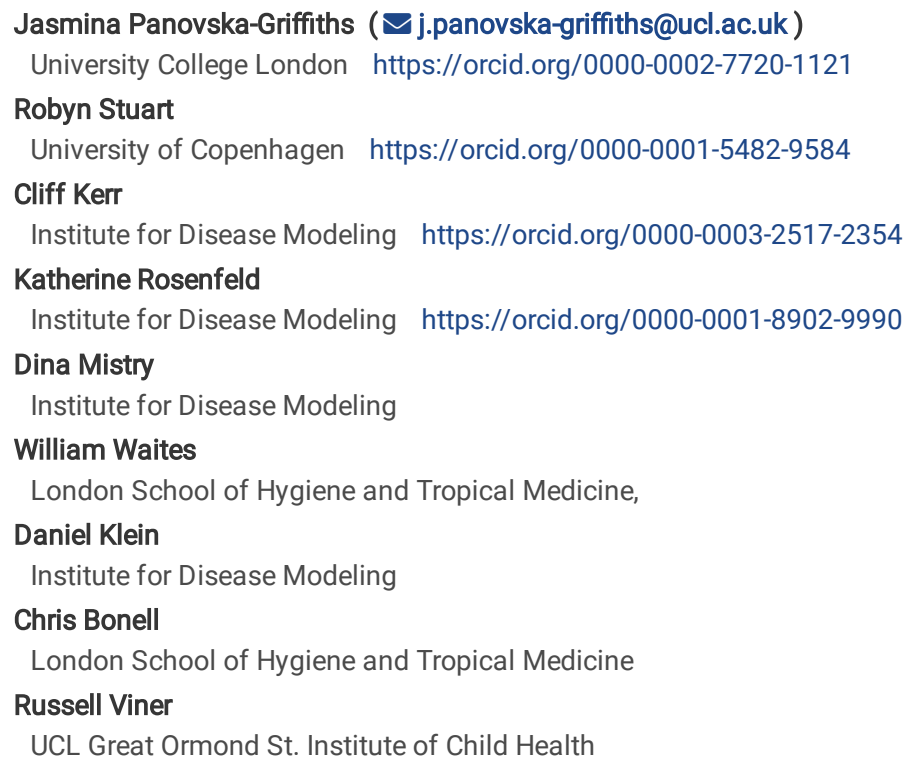




\section{Abstract}

Background Following the resurgence of the COVID-19 epidemic in the UK in late 2020 and the emergence of the new variant of the SARS-CoV-2 virus, B.1.1.7, a third national lockdown was imposed from January 5, 2021. Following the decline of COVID-19 cases over the remainder of January 2021, it is important to assess the conditions under which reopening schools from early March is likely to lead to resurgence of the epidemic. This study models the impact of a partial national lockdown with social distancing measures enacted in communities and workplaces under different strategies of reopening schools from March 8, 2021 and compares it to the impact of continual full national lockdown remaining until April 19, 2021.

Methods We used our previously published model, Covasim, to model the emergence of B.1.1.7 over September 1, 2020 to January 31, 2021. We extended the model to incorporate the impacts of the roll-out of a two-dose vaccine against COVID-19, assuming 200,000 daily doses of the vaccine in people 75 years or older with vaccination that offers $95 \%$ reduction in disease acquisition and $10 \%$ reduction of transmission blocking. We used the model, calibrated until January 25, 2021, to simulate the impact of a full national lockdown (FNL) with schools closed until April 19, 2021 versus four different partial national lockdown (PNL) scenarios with different elements of schooling open: 1) staggered PNL with primary schools and exam-entry years (years 11 and 13 ) returning on March 8, 2021 and the rest of the schools years on March 15, 2020;2) full-return PNL with both primary and secondary schools returning on March 8, 2021; 3) primary-only PNL with primary schools and exam critical years (Y11 and Y13) going back only on March 8, 2021 with the rest of the secondary schools back on April 19, 2021 and 4) part-Rota PNL with both primary and secondary schools returning on March 8, 2021 with primary schools remaining open continuously but secondary schools on a two-weekly rota-system with years alternating between a fortnight of face-to-face and remote learning until April 19, 2021. Across all scenarios, we projected the number of new daily cases, cumulative deaths and effective reproduction number $\mathrm{R}$ until April 30, 2020.

Results Our calibration across different scenarios is consistent with the new variant B.1.1.7 being around $60 \%$ more transmissible. Strict social distancing measures, i.e. national lockdowns, are required to contain the spread of the virus and control the hospitalisations and deaths during January and February 2021. The national lockdown will reduce the number of cases by early March levels similar to those seen in October with $\mathrm{R}$ also falling and remaining below 1 during the lockdown. Infections start to increase when schools open but if other parts of society remain closed this resurgence is not sufficient to bring $\mathrm{R}$ above 1. Reopening primary schools and exam critical years only or having primary schools open continuously with secondary schools on rotas will lead to lower increases in cases and $\mathrm{R}$ than if all schools open. Under the current vaccination assumptions and across the set of scenarios considered, $\mathrm{R}$ would increase above 1 if society reopens simultaneously, simulated here from April 19, 2021.

Findings Our findings suggest that stringent measures are necessary to mitigate the increase in cases and bring R below 1 over January and February 2021 . It is plausible that a PNL with schools partially open from March 8, 2021 and the rest of the society remaining closed until April 19, 2021 may keep R below 1, with some increase evident in infections compared to continual FNL until April 19, 2021. Reopening society in mid-April, with the vaccination strategy we model, could push R above 1 and induce a surge in infections, but the effect of vaccination may be able to control this in future depending on the transmission blocking properties of the vaccines.

\section{Introduction}

At the end of January 2021, the UK remained severely affected by the global COVID-19 pandemic, with over 3.8 million confirmed cases and 100 thousand deaths having been recorded since the virus was first detected in the UK more than a year prior [1].

The increase in the number of COVID-19 cases over the period from November 2020 until January 2021 has been attributed in part to the emergence of new variants of SARS-CoV-2 [2], although other factors, including so-called pandemic fatigue, have also been noted as potential causes for this [1]. One particular variant, labelled 'Variant of Concern 202012/01' (VOC 202012/01) or B.1.1.7, has been of particular import [2,3], with studies suggesting it is notably more transmissible that other strains of SARS-CoV-2 [4,5]. WHO reports from early December suggest that in the period from October 5 to December 13,2020 , over $50 \%$ of COVID-19 cases in South-East England were identified as involving B.1.1.7 [2] with retrospective analysis suggesting that the new variant had been present in South-East England from September 20, 2020 [2]

As a result of the increase in COVID-19 cases across the UK over October and November 2020, a national lockdown was imposed between November 5, 2020 and December 3, 2020 [6]. Following the release of this lockdown, COVID-19 cases, hospitalisations and deaths increased sharply during December 2020, prompting the UK Government to impose even stricter national lockdown conditions from January 5, 2021 [7], the third such lockdown that the UK had implemented. During this third national lockdown, unlike during the November 2020 lockdown, schools remain closed apart from attendance by vulnerable children and the children of key workers.

In late December 2020, a national program of vaccination against COVID-19 began across the UK, with initial phases targeting elderly people and high-priority groups such as health-care workers [8]. In its initial stages, this vaccination program included two vaccines, the Pfizer/BioNTech and the Oxford/AstraZenica vaccines, both two-dose regimes that were approved in the UK in late 2020. The current understanding is that these vaccines offer protection against severe disease with efficacy between 70-95\% [9]. The expectation is that vaccination would reduce the rate of hospitalisations and deaths in the vaccinated cohort. There are still a number of open questions regarding the efficacy of the vaccines (including whether vaccination also reduces transmission, with recent results suggesting it may $[10,11]$, whether the vaccines achieve sterilising immunity, how long the effect of the vaccine lasts, and what the optimal dosing schedule is), many of which will only be answerable after sufficient time has elapsed to see these effects in vaccinated cohorts. However, in the absence of definitive data, mathematical modelling can nevertheless help understand the possible impact of vaccines with various properties on the epidemic trajectory. This study is one of the first to incorporate vaccination against COVID-19, albeit with certain assumptions and caveats which are listed in the Methods section. 
Throughout January 2021, the UK Government indicated that the third UK national lockdown would remain in place while the roll-out of the vaccination campaign continued and until a clear indication was received that the COVID-19 surge was under control [12]. At the same time, the UK Government has also emphasised its position that schools should be the first areas of society to reopen [13]. Apart from the considerable damage to children and young people's learning [14], school closures can induce developmental, physical and mental health issues arising from lost education [15] as well as social isolation and reduced social support [16] and increased violence [17]. All of these factors are likely to present greater challenges in poorer families, consequently exacerbating inequalities. It is therefore critical to understand how various scenarios of partial or full reopening of schools in the presence of continued broader social lockdown might impact upon infections, deaths and $\mathrm{R}$ in the presence of B.1.1.7.

To answer this question, we used mathematical modelling to simulate the impact of a full national lockdown (FNL) in England from January 5 , 2021 compared to partial national lockdowns (PNL) in which some elements of in-person schooling remained open. We assessed future epidemic trajectories until the end of April 2021 in five different scenarios: 1) FNL between January 4, 2021 and April 19, 2021 with all schools closed for in-person teaching and all but vulnerable students undertaking online learning, together with comprehensive restrictive social distancing measures across society; 2 ) Staggered PNL between January 4 and March 8, 2021 with schools open for face-to-face learning from March 8, 2021 for primary schools and for years 11 and 13 of secondary schools (being exam-critical years) and the rest of secondary school years from March 15, with online learning provided for secondary students between January 4 and the start of face-to-face learning; 3) Full-retum PNL with both primary and secondary schools returning on March 8, 2021; and 4) Primary-only PNL with primary schools and exam critical year (years 11 and 13) only opened on March 8, 2021 with the rest of the secondary schools back on April 19, 2021 and 5) Part-Rota PNL with both primary and secondary schools returning on March 8, 2021 with primary students remaining in school continuously while the secondary students have two-weekly rota-system with face-to-face teaching provided for two weeks off until April 19, 2021.

All four PNL strategies within this analysis are accompanied by comprehensive social distancing measures across society. All strategies also assume that there will be a two-week holiday for all schools from April 1-April 18 and that schools are 'dismissed' rather than closed i.e. that those not in classrooms are provided with access to online learning and that face-to-face teaching is available for vulnerable children and children of key workers. In January 2021 , estimates were that around 1 in 5 primary school students are attending schools while only $5 \%$ of secondary schools students were attending [18]. For each scenario, we projected the number of new daily cases, cumulative deaths and effective reproduction number (R).

\section{Methods}

\section{Transmission model}

We used Covasim, a stochastic individual-based model of SARS-CoV-2 transmission across a population. We have previously applied Covasim to explore the impact of different test-trace-isolate strategies when schools reopened in the UK during autumn 2020 in the absence [19] and presence [20] of requirements to wear masks. Development and implementation details can be found at http://docs.covasim.org with the methodology outlined in a previous report [21]. The code used to run the simulations reported in this paper is available from https://github.com/Jasminapg/Covid-19-Analysis.

For this study, as in our previous work [7-8], we used Covasim's default parameters, pre-populated demographic data on population age structures and household sizes and contact patterns in school, community and household setting for the UK, and the population stratified across four population contact network layers: schools, workplaces, households and community settings. The per-contact transmission probability (the risk of transmission during a contact between an infectious individual and a susceptible individual) was assumed to depend on the contact network.

\section{Test, trace and isolation strategies}

Covasim accounts for testing strategies via parameters that determine the probabilities with which people with different symptoms receive a test each day, both for symptomatic and asymptomatic people. Tracing is quantified by parameters controlling the probability of reaching the contacts of those testing positive, as well as the time taken to reach them. Within Covasim we can also quantify the level of adherence to isolation as model parameters describing the level of isolation across different layers of the population.

\section{Vaccination strategies}

For this study we model a vaccine reducing disease acquisition and transmission with a two-dose regime given 10 weeks apart, to reflect our understanding of vaccination guidelines in place in January 2021 [22]. We model that the full two-dose course reduces the probability of developing symptoms by $95 \%$ and perexposure transmission probability by $10 \%$. Single dose efficacy is assumed to be $70 \%$ of the full two-dose course. Second dose is administered after a delay of 10 weeks after the first dose and with immunity from the vaccination assumed to increase from around 14 days after immunisation with full effect after 21 days after vaccination. Doses are allocated to 200,000 people per day on average, with people 75 or older targeted first.

\section{Data sources and calibration}

Using Covasim's default contact network generation algorithm, we generated a population of 100,000 agents who interact over the four contact networks layers (households, workplaces, schools, and communities), which we then rescaled to the UK population size using the dynamic rescaling algorithm described in [21].

Unlike our previous work [19-20] where we modelled one strain of the SARS-CoV-2, here we have modelled the implications of two strains of the virus by simulating a single strain with time-varying infectiousness. Specifically, we assume that the new variant is more transmissible, and that the relative proportion of the new strain increased from September 1, 2020 to January 31, 2021 following a logistic growth function, such that $30 \%$ of infections in December and 
$90 \%$ of infections by the end of January 2021 were caused by the new variant. This allowed us to model different levels of infectiousness of B.1.1.7 compared to the previous strain, in an approach similar to recent work [4].

We calibrated the model to the UK epidemic by adjusting (a) the number of infected people on January 21, 2020 (b) the per-contact transmission probability for SARS-CoV-2 (c) the parameters associates with the time-varying infectiousness of the virus (d) the testing, tracing and isolation parameters for NovemberJanuary and (e) the levels of transmission across different society levels between November 2020-January 2021. Calibration minimised the differences between the model's estimates of COVID-19 cases, deaths and severe infections and empirical data on cumulative infections, cumulative deaths and admissions to hospital by reported date between January 21, 2020 and January 25, 2021 collated from the UK government's COVID-19 dashboard (https://coronavirus.data.gov.uk).

Within the model we also simulated the effect of the two previous national lockdowns. For the first national lockdown, when schools closed and as in [19,20], we modelled a $98 \%$ reduction in the per-contact transmission probabilities from March 23,2020 within schools and an $80 \%$ reduction in transmission within workplace and community settings, and increased these in a phased way since the phased relaxing of the lockdown measures from June 1,2020 . For the second lockdown, between November 5, 2020 and December 3, 2020 during which schools remained open, we assumed a reduction in the per-contact transmission probabilities by $37 \%$ in schools i.e. simulated $63 \%$ of transmission within schools remaining from September. This was modelled as aggregated reduction in transmission due to hygiene, mask usage and other social distancing measures in place within schools to reduce transmission, and as described in details in [20].

The level of reduction in transmission in households, workplaces and community that we modelled was a combination of using Google mobility data [23] within households, workplaces and community but also fitting to data during the calibration process. Specifically, for the household transmission we modelled increased transmission since November 2020 of $25 \%$ and in line with the average monthly level of increased household mobility in the Google data [23]. For the workplaces and community, during the November lockdown, we also used Google mobility data to obtain a broad range of the change, but we also needed to adjust these during the calibration process. Specifically, we simulated workplace and community transmission to be reduced by $80 \%$ and $80 \%$ of their preCOVID-19 levels during the first lockdowns, and $70 \%$ and $60 \%$ during the second lockdown.

We also used publicly available weekly data from NHS Test and Trace to estimate the rate of tracing of contacts of those testing positive since the start of the programme on May 28, 2020 [24]. For each weekly period, we collated the percentage of people testing positive who were interviewed, the percentage of those reporting contacts and the percentage of contacts traced. We used these percentages to produce an overall estimate of the percentage of contacts of those tested positive who were traced. We then computed the monthly average effective contact tracing level and in our previous work, we used this data to produce a monthly effective contact tracing level. As an extension, here we additionally assumed that tracing levels differ depending on the type of contact, and assumed that $100 \%$ of household contacts can be traced within the same day, $50 \%$ of school and workplaces can be traced within one day and $10 \%$ of community contacts can successfully be traced within 2 days; giving an average of $53 \%$ of contacts traced across different layers and comparable with reported monthly values from [24]. We also assumed that asymptomatic testing is available across all society layers and modelled this in line with reported numbers in the UK (0.076\% May-August 2020, 0.28\% August-October 2020 and $0.63 \%$ since November 2020 from https://ourworldindata.org/coronavirustesting).

\section{Scenarios}

We modelled five different scenarios as postulated reductions in transmission within schools, community and workplaces, which are shown in Table 1 and briefly summarised below. For each scenario we predicted the number of new daily cases, cumulative deaths and R until April 30, 2021.

Scenario 1: FNL between January 5 and April 19, 2021, with all schools and reduction in transmission within workplaces, homes and community modelled as in the November 2020 lockdown until April 19.

Scenario 2: Staggered PNL: FNL between January 5 and March 8, 2021 with PNL after March 8, 2021 with all schools opening in a staggered way: primary schools and years 11 and 13 of secondary schools from March 8 and the rest of secondary school years from March 15. A reduction in transmission within workplaces, homes and community is modelled as in the November 2020 lockdown until April 19.

Scenario 3: Full-return PNL: FNL between January 5 and March 8, 2021 with PNL after March 8, 2021 with all schools opening from March 8. A reduction in transmission within workplaces, homes and community is modelled as in the November 2020 lockdown until April 19.

Scenario 4: Primary-only PNL: FNL between January 5 and March 8, 2021 with PNL after March 8, with only primary schools and exam critical years (years 11 and 13) opening on March 8 and the rest of the secondary schools opening on April 19 when society also reopens. A reduction in transmission within workplaces, homes and community is modelled as in the November 2020 lockdown until April 19.

Scenario 5: Part-Rota PNL: FNL between January 5 and March 8, 2021 with PNL after March 8 with all schools opening from March 8 with primary schools remaining continuously open but secondary schools open on a two-weeks rota system until April 19 when schools and society reopen. A reduction in transmission within workplaces, homes and community is modelled as in the November 2020 lockdown until April 19.

\section{Sensitivity analyses}

There is still some uncertainty about the relative susceptibility to the virus for children compared to adults. To account for this, in the main analysis we assume that primary school children (0-10 years old) are $50 \%$ less susceptible than secondary school children (11-18 years old) or adults (>18 years old), with 
these two latter groups having the same susceptibility [25]. The sensitivity analysis then explored whether the results changed if all age groups have the same susceptibility as adults.

There is also some contention [26] regarding the degree to which transmission in society increases as a result of schools reopening. Our main scenarios assume that it would not, but we also conduct additional sensitivity analyses to explore how the results would change if community transmission increased as a result of reopening of schools.

\section{Results}

Our calibration across different scenarios of children's susceptibility between $50-100 \%$ of that of adults', is consistent with the new variant B.1.1.7 being around $60 \%$ more transmissible.

The separate panels in Figure 1 report the epidemic projections of daily new COVID-19 cases, cumulative deaths and R (as rows) across the two scenarios (as columns) until April 30, 2021. Projections for the daily infections and total infections for each scenario over the period from February 22 and April 20,2021 are shown in Figure 2(a)-(b).

Our results suggest that strict social distancing measures, i.e. national lockdown, are required to contain the spread of the virus and control the hospitalisations and deaths during January and February 2021. We estimate that the national lockdown will reduce the number of cases by early March to a similar level as in October with $\mathrm{R}$ also falling and remaining below 1.

We find that, across each scenario, the number of new infections is expected to decrease over January and early February lockdowns. This decrease is more sustained in the FNL than any of the PNL scenarios. Impacts upon deaths are lagged, with plateauing of cumulative deaths seen from February in each scenario. This is due to the vaccine effect having been modelled with a delay of 21 days. Overall, when schools open, we predict a rise in the number of infections and increase in $\mathrm{R}$, and a possible shift in $\mathrm{R}$ above 1 once society opens also.

Reopening primary schools and exam critical years with the rest of secondary schools to reopen later, results in least increase in both infections and $\mathrm{R}$ over the study period. The opening of secondary schools would result in a larger rise in the number of infections and the R value rising to close to 1 in early March. The rise in cases is most rapid for the Staggered PNL and Full-return PNL. The Part-Rota PNL, where primary schools remain open while secondary schools are open for two-weeks and closed, with online teaching provided, for two-weeks also has an increase in cases once secondary schools open, but not sufficient to push $\mathrm{R}$ above 1. The increase in cases that pushes $\mathrm{R}$ above 1 occurs in each scenario once the rest of the society opens up on April $19,2021$.

\section{Impact of FNL}

The FNL scenario reduced R below 1 and markedly reduced new infection rates from mid-January, thus acting as an effective short-term measure for suppression of COVID-19 infections. But once the lockdown was relaxed, with some form of school reopening from March 8, we see some increase in cases and R. This is increased markedly once the rest of the society reopens as well as schools remaining open, simulated here from April 19, 2021.

\section{Impact of PNL with staggered or full schools reopening}

If, instead of continuing the $3^{\text {rd }}$ national lockdown under our FNL scenario, schools were to reopen from March 8, 2021 either fully or in a staggered way with primary schools and years 11 and 13 returning from March 8, 2021 and the rest of secondary school students from March 15, 2021, there would be an increase in new infections during March and April compared with a FNL and an increase of R to closer to 1. These scenarios would result in a higher predicted level of new infections than a FNL from the end of lockdown in February. Furthermore, fully-reopened schools or staggered PNL would result in the highest numbers of daily and cumulative cases in March and April compared to other scenarios, although confidence intervals overlap (Figure 2(a)-(b)).

\section{Impact of PNL with primary schools open}

Reopening of primary schools from March 8, 2021 with either two-weekly rota system for secondary schools or a delayed return to school for secondary school students, with secondary schools returning to face-to-face learning until April 19, 2021 would result in the least increase in new infections during March and April compared to other scenarios (Figure 2(a)) and a lesser increase in R (Figure 3).

\section{Discussion}

Our calibration is consistent with the new variant B.1.1.7 being around $60 \%$ more infectious. The model estimates there were approximately 1.2 million active infections across the UK as of January 16, 2021 implying that 1 in 60 people in the UK were infected with COVID-19 at that time. This is highly similar to most recent ONS estimates for 16 January that there were 1,149,300 (95\% credible interval: 1,082,300 to 1,220,110) active infections and approximately 1 in 59 (95\% credible interval: 1 in 62 to 1 in 55) [27]. infected across the UK. We also estimate the R may be around 0.8 by March 8, 2021 under the current epidemic trajectory.

Our modelling suggests that the reduction in cases and in R is largest with continual FNL until April 19, 2021 compared to any of the scenarios with some schools reopened. Reopening primary schools and exam critical years only, or having primary schools open continuously with secondary schools on a twoweeks on-off rota, will lead to a lower increase in cases and $\mathrm{R}$ than if all schools open.

In all scenarios, the reopening of schools together with relaxation of broader lockdown of society would lead to a rise in infection rates and rise in $\mathrm{R}$ above 1 from April 19, 2021 onwards. Hence it is important to effectively roll out a mass vaccination strategy during lockdowns; we are undertaking further work to 
examine different vaccine dosing strategies and the trade-off between the speed and the efficacy of different vaccination regimes. This is important for decisions around future mitigation of the virus resurgence once lockdowns are lifted.

Given the harms of closing schools, it is important to open them as soon as it is safe to do so, and to enact sufficient countermeasures to minimise the risks of resurgence of infections and deaths and overwhelming hospitals. Our findings suggest that reopening of schools under different scenarios, as of March 8 , 2021 may plausibly result in retaining R below 1, and thus reopening of schools at this time should remain a policy option. Reopening of secondary schools appears to result in higher infection levels and additional within-schools and society strategies may need to be employed in order to safely reopen secondaries. Strategies to achieve this could consider implementation of rota systems (as modelled here) as well as further expansion of on-site testing at schools and encouraged testing at the earliest onset of symptoms, wider use of face coverings within schools, vaccinating teachers as a priority group as well as achieving high vaccine coverage and maintain social distancing in other sectors.

We note that reopening schools when prevalence remains high in the general population may lead to an increased risk of COVID-19 transmission within schools and therefore higher cases in children and adolescents. However severe COVID-19 disease and post-inflammatory complications remain extremely rare in these age-groups [31-32].

As with any modelling study, we have made a number of assumptions when simulating the epidemic. Firstly, as in our previous work [19-20], we assumed that symptomatic infections account for $70 \%$ of onward-transmitted infections, in line with other published work [28-30]. Secondly, we have modelled the presence of B.1.1.7 by simulating time-varying infectiousness for the virus strains from September 2020. Different virus strains, emerging from mutations, can have different characteristics; one of the key ones is their transmissibility (or infectiousness) and severity. In this study, based on recent reports [4,5] we modelled infectiousness as the difference between the two viral strains; while severity remains unchanged. Simply speaking we fitted different infectiousness values for each strain, assuming that the growth rate for these strains and also that one virus strain dominates the spread within each epidemic wave. Under this assumption, we modelled the contribution from the dominating strain to induce larger infectiousness. We also note that in this work we did not assume that B117 had higher severity as there is uncertainty around this. We are undertaking follow on work that will explore the transmissibility and severity parameter space in more details. Thirdly, we did not use regional variations in cases, R value or the proportion of B.1.1.7 presence. With these assumptions on uniformity of the virus spread, and the hypothesis on the two strains, we note that we may underestimate the number of new infections because we don't explicitly model how much the new variant predominate and how across different regions. It is possible that the future spread across different regions may lead to increased net transmissibility. In a follow up study, we will focus on exploring this for London specifically - one of the hotspots at the onset of the second epidemic wave.

However, unlike previous work [19-20] that had set the level of contact tracing to be the same across all contact network layers, in this work we used different tracing levels across layers. We have assumed that tracing within households will be $100 \%$ effective within the same day, while within schools and workplaces it will be $50 \%$ effective within one day. i.e. will miss about half of the cases within one day. We arrived at this level during the calibration process, but we acknowledge that this may be an underestimation if effective cohorting is in place. However, within the community the tracing is generally difficult. For example, NHS Test and Trace report that the fraction of contacts is easy to reach in both complex (e.g. schools and workplaces) and non-complex cases (e.g. households). This suggests that cases have better tracing in institutions where contacts identities are better known. The fraction of contacts reached within the community are not reported and we expect that challenges associated with finding, tracing and isolating are with contacts in the community; within the model we have assumed that only $10 \%$ of the community contacts are traced within two days. With these assumptions across layers, the average tracing level is around $53 \%$ which is agreeable with recent reported values [24].

As with any stochastic modelling, there is uncertainty in our predictions, most notably in the confidence intervals in Figure 2(a). Our results are based on taking median simulation from a stochastic process with a degree of uncertainty may increase when making longer time future predictions. Hence, in Figures 1-2 we only project for 8 weeks into the future from March 8, 2021 and note that projecting results of any model, including ours, too far into the future based on current data is unwise due to the high level of uncertainty. Importantly, estimation of future epidemic trajectories will depend on the effect of the continual rollout of mass vaccination against COVID-19 and further additions to it.

In summary, our findings offer evidence that the current national lockdown with schools closed is likely to successfully control this pandemic wave. We also provide tentative evidence that it may be possible to control virus spread with cautious reopening of schools from March 8,2021 whilst continuing the current vaccination efforts.

\section{Declarations}

\section{Licence statement}

The Corresponding Author has the right to grant on behalf of all authors and does grant on behalf of all authors, an exclusive licence (or non exclusive for government employees) on a worldwide basis to the BMJ Publishing Group Ltd to permit this article (if accepted) to be published in BMJ editions and any other BMJPGL products and sublicences such use and exploit all subsidiary rights, as set out in our licence

\section{Competing interest statement}

All authors have completed the Unified Competing Interest form and declare: no support from any organisation for the submitted work, no financial relationships with any organisations that might have an interest in the submitted work in the previous three, no other relationships or activities that could appear to have influenced the submitted work.

\section{Contribution}


JPG and RV came up with the idea of the study. JPG, RMS and KR developed the specific modelling framework, based on the Covasim model developed by CCK, RMS, DM and DJK. CCK, RMS, DM, DJK, KR and JPG collated data for the parameters used. JPG ran the modelling analysis with input from RMS and KR. JPG, RV and CB defined the different scenarios in the UK context following conversations with Scientific Pandemic Influenza Modelling Group and Scientific Pandemic Influenza Behaviour Group which give expert advice to the UK Department of Health and Social Care and wider UK Government. JPG wrote the manuscript with input from RMS, CB, RV, CCK, KR, WW, DM and DJK. All authors approved the final version. JPG is the manuscript's guarantor.

\section{Transparency declaration}

Manuscript's guarantor affirms that the manuscript is an honest, accurate, and transparent account of the study being reported; that no important aspects of the study have been omitted; and that any discrepancies from the study as planned have been explained.

\section{Ethical approval}

This is a modelling study for which publicly available data from https://coronavirus.data.gov.uk were used and no ethical approval was required.

\section{Patient and public involvement statement}

Patients or the public were not involved in the design, or conduct, or report, or dissemination plans of this research.

\section{Statement on data quality}

All data and numerical code used in this analysis are available at https://github.com/Jasminapg/Covid-19-Analysis

\section{References}

1. Pandemic fatigue. https://apps.who.int/iris/bitstream/handle/10665/335820/WHO-EURO-2020-1160-40906-55390-eng.pdf and https://blogs.bmj.com/bmj/2021/01/07/pandemic-fatigue-how-adherence-to-covid-19-regulations-has-been-misrepresented-and-why-it-matters/, accessed 03/02/2021.

2. Public Health England, Investigation of novel SARS-CoV-2 variant: Variant of Concem 202012/01 (2020), <backgroundcolor:\#FF3300;bu>https://www.gov.uk/government/publications/investigation-of-novel-sars-cov-2-variant-variant-of-concern-20201201</backgroundcolor:\#FF3300;bu>, accessed 27/12/2020.

3. SARS-CoV-2 Variant - United Kingdom of Great Britain and Northern Ireland, WHO report, <backgroundcolor:\#FF3300;bu>https://www.who.int/csr/don/21-december-2020-sars-cov2-variant-united-kingdom/en/</background-color:\#FF3300;bu>, assessed $28 / 12 / 2020$.

4. Davies NG, Barnard RC, et al. Estimated transmissibility and severity of novel SARS-CoV-2 Variant of Concern 202012/01 in England. medRxiv (2020) doi: https://doi.org/10.1101/2020.12.24.20248822

5. Volz E, Mushra S, et al. Transmission of SARS-CoV-2 Lineage B.1.1.7 in England: Insights from linking epidemiological and genetic data. medRxiv 2020.12.30.20249034; doi:https://doi.org/10.1101/2020.12.30.20249034.

6. COVID-19: PM announces four-week England lockdown, <background-color:\#FF3300;bu>https://www.bbc.co.uk/news/uk-54763956</backgroundcolor:\#FF3300;bu>, accessed 20/12/2020.

7. Prime Minister announces national lockdown https://www.gov.uk/government/news/prime-minister-announces-national-lockdown, accessed 20/01/2021.

8. The COVID-19 vaccines: who gets it first? Health Foundation Report. https://www.health.org.uk/publications/long-reads/the-covid-19-vaccine-who-gets-itfirst accessed 03/02/2021.

9. Covid-19 vaccination: What's the evidence for extending the dose interval? News analysis. BMJ 2021; 372 doi: https://doi.org/10.1136/bmj.n18 https://www.bmj.com/content/372/bmj.n18 accessed 03/02/2021.

10. Can you still transmit COVID-19 after vaccination? https://www.bbc.com/future/article/20210203-why-vaccinated-people-may-still-be-able-to-spreadcovid-19 accessed 03/02/2021

11. Lipsitch M, Dean NE. Understanding COVID-19 vaccine efficacy. Science 370, 763-765 (2020). doi:10.1126/science.abe5938pmid:33087460

12. Prime Minister's statement to the House of Commons on coronavirus: 27 January $2021 \mathrm{https}: / /$, accessed 02/02/2021.

13. Coronavirus: Boris Johnson says schools will be the first to open after lockdown https://www.bbc.co.uk/news/av/uk-55561656, accessed 02/02/2021.

14. Pearcey S, Shum A, Waite P, et al. Report 04: Changes in children and young people's emotional and behavioural difficulties through lockdown. Oxford: CoSPACE study, 2020.

15. Pierce M, Hope H, Ford T, et al. Mental Health Before and During the COVID-19 Pandemic: A Longitudinal Probability Sample Survey of the UK Population. SSRN preprint server 2020 doi: http://dx.doi.org/10.2139/ssrn.3624264 [published Online First: 6 May 2020]

16. Loades ME, Chatburn E, Higson-Sweeney N, et al. Rapid Systematic Review: The Impact of Social Isolation and Loneliness on the Mental Health of Children and Adolescents in the Context of COVID-19. J Am Acad Child Adolesc Psychiatry 2020 doi: 10.1016/j.jaac.2020.05.009 [published Online First: 2020/06/07]

17. Sidpra J, Abomeli D, Hameed B, et al. Rise in the incidence of abusive head trauma during the COVID-19 pandemic. Arch Dis Child 2020 doi: 10.1136/archdischild-2020-319872 [published Online First: 2020/07/04] 
18. Restricting during the national lockdown: schools

https://assets.publishing.service.gov.uk/government/uploads/system/uploads/attachment_data/file/957766/Restricting_attendance_during_the_nationa _schools.pdf, accessed 02/02/2021.

19. Panovska-Griffiths J, Kerr CC, Stuart RM, Mistry D, Klein DJ, Viner RM, Bonell C. Determining the optimal strategy for reopening schools, workplaces and society in the UK: modelling patterns of reopening, the impact of test and trace strategies and risk of occurrence of a secondary COVID-19 pandemic wave. <bi>The Lancet Child \& Adolescent Health (2020) 4:817 - 27</bi> doi:10.1016/ S2352-4642(20)30250-9

20. Panovska-Griffiths J., Kerr CC, Stuart RM, Mistry D, Klein DJ, Viner RM, Bonell C Modelling the potential impact of mask use in schools and society on COVID-19 control in the UK. (2020) <bi>Scientific Reports. (accepted and finalising proof)</bi> preprint doi:10.1101/2020.09.28.20202937.

21. Kerr C.C. et al. Covasim: an agent-based model of COVID-19 dynamics and interventions. medRxiv preprint (2020). doi: https://doi.org/10.1101/2020.05.10.20097469

22. UK vaccines delivery plan report. https://www.gov.uk/government/publications/uk-covid-19-vaccines-delivery-plan/uk-covid-19-vaccines-delivery-plan, accessed 03/02/2021,

23. Google, COVID-19 Community Mobility Reports, <background-color:\#FF3300;bu>https://www.google.com/covid19/mobility/</backgroundcolor:\#FF3300;bu>, accessed 29/12/2020.

24. Weekly statistics for NHS Test and Trace (England) and coronavirus testing (UK). Accessed 20/12/2020. https://www.gov.uk/government/collections/nhs-test-and-trace-statistics-england-weekly-reports

25. Viner RM, Mytton OT, Bonell C, et al. Susceptibility to SARS-CoV-2 Infection Among Children and Adolescents Compared With Adults: A Systematic Review and Meta-analysis. JAMA Pediatr. 2021;175(2):143-156. doi:10.1001/jamapediatrics.2020.4573

26. Flasche S, WJ Edmunds. The role of schools and school-aged children in SARS-CoV-2 transmission Lancet Infect Dis, published online December $8,2020$. https://doi.org/10.1016/ S1473-3099(20)30927-0

27. Coronavirus (COVID-19) weekly insights: latest health indicators in England, 8 January 2021, accessed 13/01/2020. https://www.ons.gov.uk/peoplepopulationandcommunity/healthandsocialcare/conditionsanddiseases/articles/coronaviruscovid19weeklyinsights/latestl

28. Kucharski AJ, Klepac P, Conlan AJK, et al. Effectiveness of isolation, testing, contact tracing, and physical distancing on reducing transmission of SARSCoV-2 in different settings: a mathematical modelling study [published online ahead of print, 2020 Jun 15]. Lancet Infect Dis. 2020;S14733099(20)30457-6. doi:10.1016/S1473-3099(20)30457-6

29. Hellewell J, Abbott S, Gimma A, et al. Feasibility of controlling COVID-19 outbreaks by isolation of cases and contacts [published correction appears in Lancet Glob Health. 2020 Mar 5;:]. Lancet Glob Health. 2020;8(4):e488-e496. doi:10.1016/S2214-109X(20)30074-7

30. Flaxman S, Mishra S, Gandy A, et al. Estimating the effects of non-pharmaceutical interventions on COVID-19 in Europe. Nature. 2020;584(7820):257261. doi:10.1038/s41586-020-2405-7

31. Toubiana Julie, Poirault Clément, Corsia Alice, Bajolle Fanny, Fourgeaud Jacques, AngoulvantFrançois et al. Kawasaki-like multisystem inflammatory syndrome in children during the covid-19 pandemic in Paris, France: prospective observational study BMJ 2020;369:m2094

32. Snape MD, Viner RM. COVID-19 in children and young people, Science, 370(6514), pp. 286-288, doi: 10.1126/science.abd6165

\section{Table}




\begin{tabular}{|c|c|c|c|c|c|}
\hline Scenarios & Assumptions & $\begin{array}{l}\text { Household } \\
\text { contacts }\end{array}$ & School contacts & $\begin{array}{l}\text { Work } \\
\text { contacts }\end{array}$ & $\begin{array}{l}\text { Community } \\
\text { contacts }\end{array}$ \\
\hline $\begin{array}{r}\text { Full National Lockdown until } 6^{\text {th }} \\
\text { April (FNL) }\end{array}$ & $\begin{array}{l}\text { - National lockdown effective between } 5^{\text {th }} \quad \text { January- } 19^{\text {th }} \text { April } \\
2021 \text { with all schools and society closed. } \\
\text {-School holiday } 1^{\text {st }} \text { April- } 19^{\text {th }} \text { April } 2021 \\
\text { The transmission in society during } 3^{\text {rd }} \text { lockdown is assumed to } \\
\text { be as per November } 20202^{\text {nd }} \text { lockdown i.e. } \\
-30 \% \text { transmission in workplaces } \\
-40 \% \text { transmission across communities } \\
\text { but increased virus per-person transmission probability by } 60- \\
63 \%\end{array}$ & $\begin{array}{l}\text { Increased } \\
\text { by } 25 \% \\
\text { during } \\
\text { lockdowns } \\
\text { Increased } \\
\text { by } 50 \% \text { on } \\
25^{\text {th }}, 26^{\text {th }} \\
31^{\text {st }} \\
\text { December } \\
2020\end{array}$ & $\begin{array}{l}2 \% 23^{\text {rd }} \text { March-31 } \\
\text { May } 2020 \\
21 \% 1^{\text {st }} \text { June- } 14^{\text {th }} \text { June } \\
2020 \\
36 \% 15^{\text {th }} \text { June }-24^{\text {th }} \\
\text { July } 2020 \\
63 \% \text { from } 1^{\text {st }} \\
\text { September } 2020 \text { and } \\
\text { during term-time } \\
2 \% \text { during school } \\
\text { holidays and during } \\
\text { first lockdown } \\
20 \% \text { attendance during } \\
\text { third national } \\
\text { lockdown } \\
\text { (transmission of } 14 \% \\
\text { as a result of school } \\
\text { measures) }\end{array}$ & $\begin{array}{l}20 \% 23^{\text {rd }} \\
\text { March-31 } \\
\text { May } 2020 \\
40 \% 1^{\text {st }} \\
\text { June- } 14^{\text {th }} \\
\text { June } 2020 \\
50 \% 15^{\text {th }} \\
\text { June }-24^{\text {th }} \\
\text { July } 2020 \\
50 \% \text { from } \\
1^{\text {st }} \\
\text { September } \\
2020 \text { and } \\
\text { during } \\
\text { term-time } \\
40 \% \text { during } \\
\text { school } \\
\text { holidays } \\
20 \% \text { during } \\
\text { first } \\
\text { lockdown } \\
40 \% \text { during } \\
2^{\text {nd }} \text { and } \\
30 \% \text { during } \\
3^{\text {rd }} \\
\text { lockdown }\end{array}$ & $\begin{array}{l}20 \% 23^{\text {rd }} \\
\text { March-31 } \\
\text { May } 2020 \\
30 \% 1^{\text {st }} \text { June- } \\
5^{\text {th }} \text { May } 2020 \\
50 \% 15^{\text {th }} \text { June } \\
-1^{\text {st }} \text { Sep } 2020 \\
70 \% 1^{\text {st }} \text { Sep } \\
-26^{\text {th }} \text { Oct } 2020 \\
40 \% 26^{\text {th }} \text { Oct } \\
-5^{\text {th }} \text { Nov } 2020 \\
30 \% 5^{\text {th }} \text { Nov } \\
-3^{\text {rd }} \text { Dec } 2020 \\
70 \% 3^{\text {rd }} \text { Dec- } \\
20^{\text {th }} \text { Dec } 2020 \\
90 \% \text { on } 25^{\text {th }} \\
26^{\text {th }} \text { and } 31^{\text {st }} \\
\text { Dec } 2020 \\
40 \% 1^{\text {st }} \text { Jan- } \\
8^{\text {th }} \text { March } \\
2021 \\
40 \% \text { or } 50 \% \\
8^{\text {th }} \text { March- } \\
19^{\text {th }} \text { April } 2021 \\
\text { (depending on } \\
\text { analysis) } \\
70 \% \text { from } 19^{\text {th }} \\
\text { April }\end{array}$ \\
\hline $\begin{array}{r}P N L \text { with schools open in a } \\
\text { staggered way (Staggered schools } \\
P N L)\end{array}$ & $\begin{array}{l}\text { - National lockdown effective between } 5^{\text {th }} \text { January- } 8^{\text {th }} \text { March } \\
2021 \text { with schools and society closed. } \\
\text {-Reopening of schools from } 8^{\text {th }} \text { March with primary schools and } \\
\text { years } 11 \text { and } 13 \text { going back then and the rest of schools back } \\
\text { on } 15^{\text {th }} \text { March. } \\
\text { - School holiday } 1^{\text {st }} \text { April- } 19^{\text {th }} \text { April } \\
\text { The transmission in society is assumed to be as per November } \\
2^{\text {nd }} \text { lockdown i.e. } \\
-30 \% \text { transmission in workplaces } \\
-40 \% \text { transmission across communities } \\
\text { but increased virus per-person transmission probability by } 60- \\
63 \%\end{array}$ & $100 \%$ & 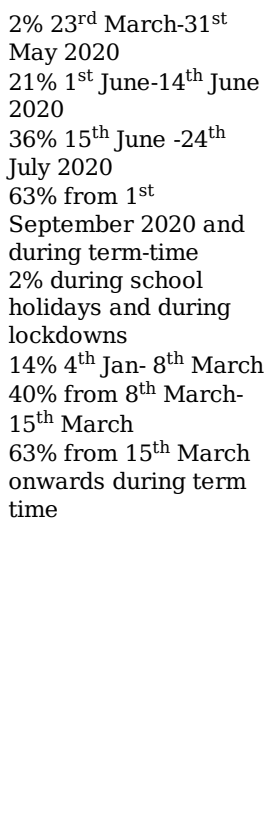 & $\begin{array}{l}20 \% 23^{\text {rd }} \\
\text { March-31 } \\
\text { May } 2020 \\
40 \% 1^{\text {st }} \\
\text { June- } 14^{\text {th }} \\
\text { June } 2020 \\
50 \% 15^{\text {th }} \\
\text { June }-24^{\text {th }} \\
\text { July } 2020 \\
50 \% \text { from } \\
1^{\text {st }} \\
\text { September } \\
2020 \text { and } \\
\text { during } \\
\text { term-time } \\
40 \% \text { during } \\
\text { school } \\
\text { holidays } \\
20 \% \text { during } \\
\text { first } \\
\text { lockdown } \\
40 \% \text { during } \\
2^{\text {nd }} \text { and } \\
30 \% \text { during } \\
3^{\text {rd }} \\
\text { lockdown }\end{array}$ & $\begin{array}{l}20 \% 23^{\text {rd }} \\
\text { March-31 } \\
\text { May } 2020 \\
30 \% 1^{\text {st }} \text { June- } \\
5^{\text {th }} \text { May } 2020 \\
50 \% 15^{\text {th }} \text { June } \\
-1^{\text {st }} \text { Sep } 2020 \\
70 \% 1^{\text {st }} \text { Sep } \\
-26^{\text {th }} \text { Oct } 2020 \\
40 \% 26^{\text {th }} \text { Oct } \\
-5^{\text {th }} \text { Nov } 2020 \\
30 \% 5^{\text {th }} \text { Nov } \\
-3^{\text {rd }} \text { Dec } 2020 \\
70 \% 3^{\text {rd }} \text { Dec- } \\
20^{\text {th }} \text { Dec } 2020 \\
90 \% \text { on } 25^{\text {th }} \\
26^{\text {th }} \text { and } 31^{\text {st }} \\
\text { Dec } 2020 \\
40 \% 1^{\text {st }} \text { Jan- } \\
8^{\text {th }} \text { March } \\
2021 \\
40 \% \text { or } 50 \% \\
8^{\text {th }} \text { March-19 } \\
\text { April } 2021 \\
\text { (depending on } \\
\text { analysis) } \\
70 \% \text { from } 19^{\text {th }} \\
\text { April } 2021\end{array}$ \\
\hline $\begin{array}{r}\text { PNL with All Schools fully open } \\
\text { from } 22^{\text {nd }} \text { February (All Schools } \\
\text { PNL) }\end{array}$ & $\begin{array}{l}\text { - National lockdown effective between } 5^{\text {th }} \text { January- } 8^{\text {th }} \text { March } \\
2021 \text { with all schools and society closed. } \\
\text { - Schools reopen fully with all years going back from } 8^{\text {th }} \text { March } \\
\text {-School holiday } 1^{\text {st }} \text { April- } 19^{\text {th }} \text { April } \\
\text { The transmission is assumed to be as per November } 20202^{\text {nd }} \\
\text { lockdown i.e. } \\
-30 \% \text { transmission in workplaces } \\
-40 \% \text { transmission across communities } \\
\text { but increased virus per-person transmission probability by } 60- \\
63 \%\end{array}$ & $100 \%$ & $\begin{array}{l}2 \% 23^{\text {rd }} \text { March-31 } \\
\text { May } 2020 \\
21 \% 1^{\text {st }} \text { June- } 14^{\text {th }} \text { June } \\
2020 \\
36 \% 15^{\text {th }} \text { June }-24^{\text {th }} \\
\text { July } 2020 \\
63 \% \text { from } 1^{\text {st }} \\
\text { September } 2020 \text { and } \\
\text { during term-time } \\
2 \% \text { during school } \\
\text { holidays and during } \\
\text { lockdowns } \\
14 \% 4^{\text {th }} \text { Jan- } 8^{\text {th }} \text { March } \\
2021 \\
63 \% \text { from } 8^{\text {th }} \text { March } \\
2021 \text { onwards during } \\
\text { term time }\end{array}$ & $\begin{array}{l}20 \% 23^{\text {rd }} \\
\text { March-31 } \\
\text { May } 2020 \\
40 \% 1^{\text {st }} \\
\text { June- } 14^{\text {th }} \\
\text { June } 2020 \\
50 \% 15^{\text {th }} \\
\text { June }-24^{\text {th }} \\
\text { July } 2020 \\
50 \% \text { from } \\
1^{\text {st }} \\
\text { September } \\
2020 \text { and } \\
\text { during } \\
\text { term-time } \\
40 \% \text { during } \\
\text { school } \\
\text { holidays } \\
20 \% \text { during } \\
\text { first } \\
\text { lockdown } \\
40 \% \text { during } \\
2^{\text {nd }} \text { and }\end{array}$ & $\begin{array}{l}20 \% 23^{\text {rd }} \\
\text { March- } 31^{\text {st }} \\
\text { May } 2020 \\
30 \% 1^{\text {st }} \text { June- } \\
5^{\text {th }} \text { May } 2020 \\
50 \% 15^{\text {th }} \text { June } \\
-1^{\text {st }} \text { Sep } 2020 \\
70 \% 1^{\text {st }} \text { Sep } \\
-26^{\text {th }} \text { Oct } 2020 \\
40 \% 26^{\text {th }} \text { Oct } \\
-5^{\text {th }} \text { Nov } 2020 \\
30 \% 5^{\text {th }} \text { Nov } \\
-3^{\text {rd }} \text { Dec } 2020 \\
70 \% 3^{\text {rd }} \text { Dec- } \\
20^{\text {th }} \text { Dec } 2020 \\
90 \% \text { on } 25^{\text {th }} \\
26^{\text {th }} \text { and } 31^{\text {st }} \\
\text { Dec } 2020 \\
40 \% 1^{\text {st }} \text { Jan- } \\
8^{\text {th }} \text { March } \\
2021 \\
40 \% \text { or } 50 \% \\
8^{\text {th }} \text { March- } 19^{\text {th }}\end{array}$ \\
\hline
\end{tabular}




\begin{tabular}{|c|c|c|c|c|c|}
\hline & & & & $\begin{array}{l}30 \% \text { during } \\
3^{\text {rd }} \\
\text { lockdown }\end{array}$ & $\begin{array}{l}\text { April } 2021 \\
\text { (depending on } \\
\text { analysis) } \\
70 \% \text { from } 19^{\text {th }} \\
\text { April } 2021\end{array}$ \\
\hline $\begin{array}{r}\text { PNL with Primary Schools and } \\
\text { exam critical years } 11 \text { and } 13 \text { open } \\
\text { before Easter (Primary Schools } \\
P N L)\end{array}$ & $\begin{array}{l}\text { - National Lockdown effective between } 5^{\text {th }} \text { January- } 8^{\text {th }} \text { March } \\
2021 \text { with all schools and society closed. } \\
\text {-Schools reopen from } 8^{\text {th }} \text { March } 2021 \text { with primary schools and } \\
\text { years } 11 \text { and } 13 \text { back then, and the rest of schools years back } \\
\text { on } 19^{\text {th }} \text { April } 2021 \\
- \text {-School holiday } 1^{\text {st }} \text { April- } 19^{\text {th }} \text { April } 2021 \\
\\
\text { The transmission is assumed to be as per November } 20202^{\text {nd }} \\
\text { lockdown i.e. } \\
-30 \% \text { transmission in workplaces } \\
-40 \% \text { transmission across communities } \\
\text { but increased virus per-person transmission probability by } 60- \\
63 \%\end{array}$ & $100 \%$ & $\begin{array}{l}2 \% 23^{\text {rd }} \text { March- } 31^{\text {st }} \\
\text { May } 2020 \\
21 \% 1^{\text {st }} \text { June- } 14^{\text {th }} \text { June } \\
2020 \\
36 \% 15^{\text {th }} \text { June }-24^{\text {th }} \\
\text { July } 2020 \\
63 \% \text { from } 1^{\text {st }} \\
\text { September } 2020 \text { and } \\
\text { during term-time } \\
2 \% \text { during school } \\
\text { holidays and during } \\
\text { lockdowns } \\
40 \% 8^{\text {th }} \text { March- } 19^{\text {th }} \\
\text { April } 2021 \\
63 \% \text { from } 19^{\text {th }} \text { April } \\
2021 \text { onwards during } \\
\text { term time }\end{array}$ & $\begin{array}{l}20 \% 23^{\text {rd }} \\
\text { March-31st } \\
\text { May } 2020 \\
40 \% 1^{\text {st }} \\
\text { June- } 14^{\text {th }} \\
\text { June } 2020 \\
50 \% 15^{\text {th }} \\
\text { June }-24^{\text {th }} \\
\text { July } 2020 \\
50 \% \text { from } \\
1^{\text {st }} \\
\text { September } \\
2020 \text { and } \\
\text { during } \\
\text { term-time } \\
40 \% \text { during } \\
\text { school } \\
\text { holidays } \\
20 \% \text { during } \\
\text { first } \\
\text { lockdown } \\
40 \% \text { during } \\
2^{\text {nd }} \text { and } \\
30 \% \text { during } \\
3^{\text {rd }} \\
\text { lockdown }\end{array}$ & $\begin{array}{l}20 \% 23^{\text {rd }} \\
\text { March-31 } 31^{\text {st }} \\
\text { May } 2020 \\
30 \% 1^{\text {st } J u n e-~} \\
5^{\text {th }} \text { May } 2020 \\
50 \% 15^{\text {th }} \text { June } \\
-1^{\text {st }} \text { Sep } 2020 \\
70 \% 1^{\text {st }} \text { Sep } \\
-26^{\text {th }} \text { Oct } 2020 \\
40 \% 26^{\text {th }} \text { Oct } \\
-5^{\text {th }} \text { Nov } 2020 \\
30 \% 5^{\text {th }} \text { Nov } \\
-3^{\text {rd }} \text { Dec } 2020 \\
70 \% 3^{\text {rd }} \text { Dec- } \\
20^{\text {th }} \text { Dec } 2020 \\
90 \% \text { on } 25^{\text {th }} \\
26^{\text {th }} \text { and } 31^{\text {st }} \\
\text { Dec } 2020 \\
40 \% 1^{\text {st }} \text { Jan- } \\
8^{\text {th }} \text { March } \\
2021 \\
40 \% \text { or } 50 \% \\
8^{\text {th }} \text { March- } 19^{\text {th }} \\
\text { April } 2021 \\
\text { (depending on } \\
\text { analysis) } \\
70 \% \text { from } 19^{\text {th }} \\
\text { April } 2021\end{array}$ \\
\hline $\begin{array}{l}\text { Primary schools open continuously } \\
\text { from } 22^{\text {2d }} \text { February with secondary } \\
\text { schools open in a two-weeks on-off } \\
\text { rota from 22nd February (Schools- } \\
\text { rota PNL) }\end{array}$ & $\begin{array}{l}\text { - National lockdown effective between } 5^{\text {th }} \text { January- } 8^{\text {th }} \text { March } \\
2021 \text { with all schools back then. Primary schools remain on } \\
\text { continuously but secondary schools open are on rota-basis with } \\
\text { two weeks on and two weeks off. All schools return normally } \\
\text { from } 19^{\text {th }} \text { April } 2021 \text {. } \\
\text {-School holiday } 1^{\text {st }} \text { April- } 19^{\text {th }} \text { April } 2021 \\
\text { The transmission is assumed to be as per November } 20202^{\text {nd }} \\
\text { lockdown i.e. } \\
-30 \% \text { transmission in workplaces } \\
-40 \% \text { transmission across communities } \\
\text { but increased virus per-person transmission probability by } 60- \\
63 \% \%\end{array}$ & $100 \%$ & $\begin{array}{l}2 \% 23^{\text {rd }} \text { March-31 } \\
\text { May } 2020 \\
21 \% 1^{\text {st }} \text { June- } 14^{\text {th }} \text { June } \\
2020 \\
36 \% 15^{\text {th }} \text { June }-24^{\text {th }} \\
\text { July } 2020 \\
63 \% \text { from } 1^{\text {st }} \\
\text { September } 2020 \text { and } \\
\text { during term-time } \\
2 \% \text { during school } \\
\text { holidays and during } \\
\text { lockdowns } \\
63 \% 4^{\text {th }} \text { Jan- } 8^{\text {th }} \text { March } \\
2021 \\
31 \% 8^{\text {th }} \text { March }-22^{\text {nd }} \\
\text { March } 2021 \\
63 \% 22^{\text {nd }} \text { March-2 } 29^{\text {th }} \\
\text { March } 2021 \\
63 \% \text { from } 19^{\text {th }} \text { April } \\
2021 \text { onwards during } \\
\text { term time }\end{array}$ & $\begin{array}{l}20 \% 23^{\text {rd }} \\
\text { March-31 } \\
\text { May } 2020 \\
40 \% 1^{\text {st }} \\
\text { June- } 14^{\text {th }} \\
\text { June } 2020 \\
50 \% 15^{\text {th }} \\
\text { June }-24^{\text {th }} \\
\text { July } 2020 \\
50 \% \text { from } \\
1^{\text {st }} \\
\text { September } \\
2020 \text { and } \\
\text { during } \\
\text { term-time } \\
40 \% \text { during } \\
\text { school } \\
\text { holidays } \\
20 \% \text { during } \\
\text { first } \\
\text { lockdown } \\
40 \% \text { during } \\
2^{\text {nd }} \text { and } \\
30 \% \text { during } \\
3^{\text {rd }} \\
\text { lockdown }\end{array}$ & $\begin{array}{l}20 \% 23^{\text {rd }} \\
\text { March-31 } 31^{\text {st }} \\
\text { May } 2020 \\
30 \% 1^{\text {st }} \text { June- } \\
5^{\text {th }} \text { May } 2020 \\
50 \% 15^{\text {th }} \text { June } \\
-1^{\text {st }} \text { Sep } 2020 \\
70 \% 1^{\text {st }} \text { Sep } \\
-26^{\text {th }} \text { Oct } 2020 \\
40 \% 26^{\text {th }} \text { Oct } \\
-5^{\text {th }} \text { Nov } 2020 \\
30 \% 5^{\text {th }} \text { Nov } \\
-3^{\text {rd }} \text { Dec } 2020 \\
70 \% 3^{\text {rd }} \text { Dec- } \\
20^{\text {th }} \text { Dec } 2020 \\
90 \% \text { on } 25^{\text {th }} \\
26^{\text {th }} \text { and } 31^{\text {st }} \\
\text { Dec } 2020 \\
40 \% 1^{\text {st }} J a n- \\
8^{\text {th }} \text { March } \\
2021 \\
40 \% \text { or } 50 \% \\
8^{\text {th }} \text { March- } 19^{\text {th }} \\
\text { April } 2021 \\
\text { (depending on } \\
\text { analysis) } \\
70 \% \text { from } 19^{\text {th }} \\
\text { April } 2021\end{array}$ \\
\hline
\end{tabular}

Table 1: Scale factors applied to daily SARS-CoV-2 transmission probabilities in households, schools, workplaces, and the community under the three simulated scenarios

\section{Figures}




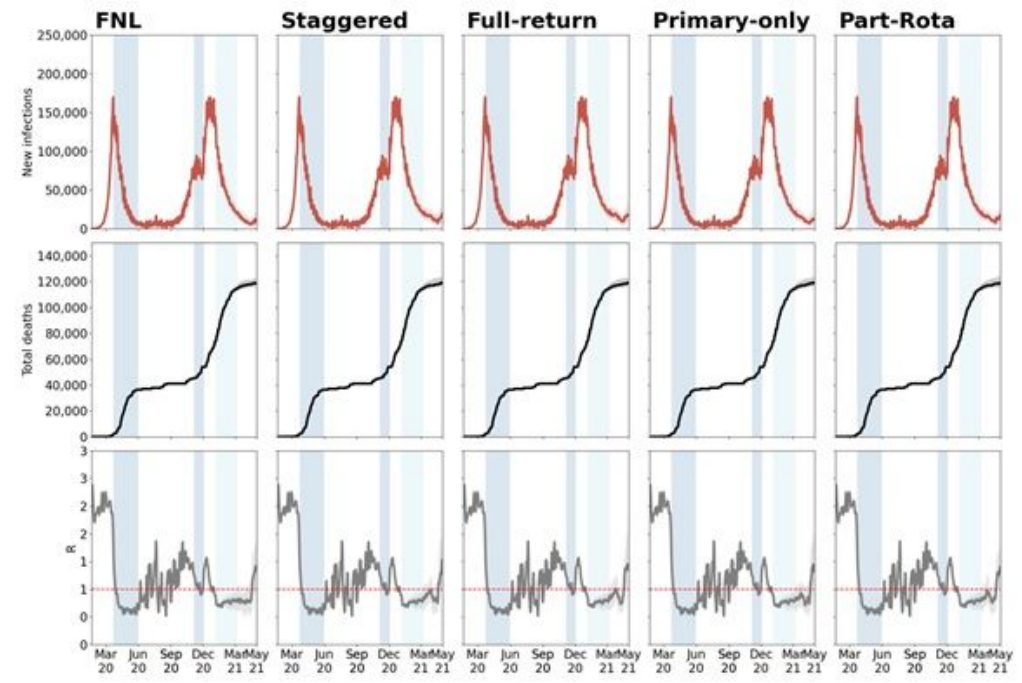

\section{Figure 1}

Model-predicted epidemic trajectories of the calibrated model until April 30, 2021 across FNL and PNL with different reopening strategies and under the assumption that susceptibility in 0-10 years old is $50 \%$ less than across other ages and that community transmission remains the same as in November lockdown between March 8,2021 and April 19, 2021. Medians across 30 simulations are indicated by solid lines and the $25 \%$ and $75 \%$ quantiles by shading. The blue bands represent the past and current national lockdowns.
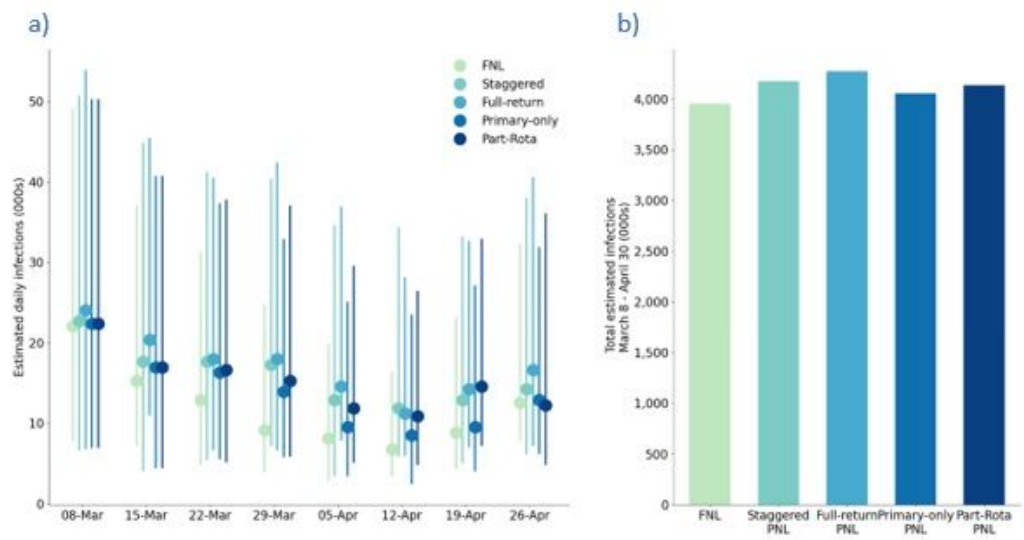

\section{Figure 2}

Model predicted estimated daily (a) and total (b) infections in the period from February 22 to April 20, 2021 from the calibrated model across the five different scenarios: FNL, Staggered PNL, Full-return PNL, Primary-only PNL and Part-Rota PNL under the assumption that susceptibility in 0-10 years old is $50 \%$ less than across other ages and that community transmission remains the same as in November lockdown between March 8,2021 and April 19, 2021 . In (a) we show the point estimates as well as the uncertainty range around this for each scenario. 


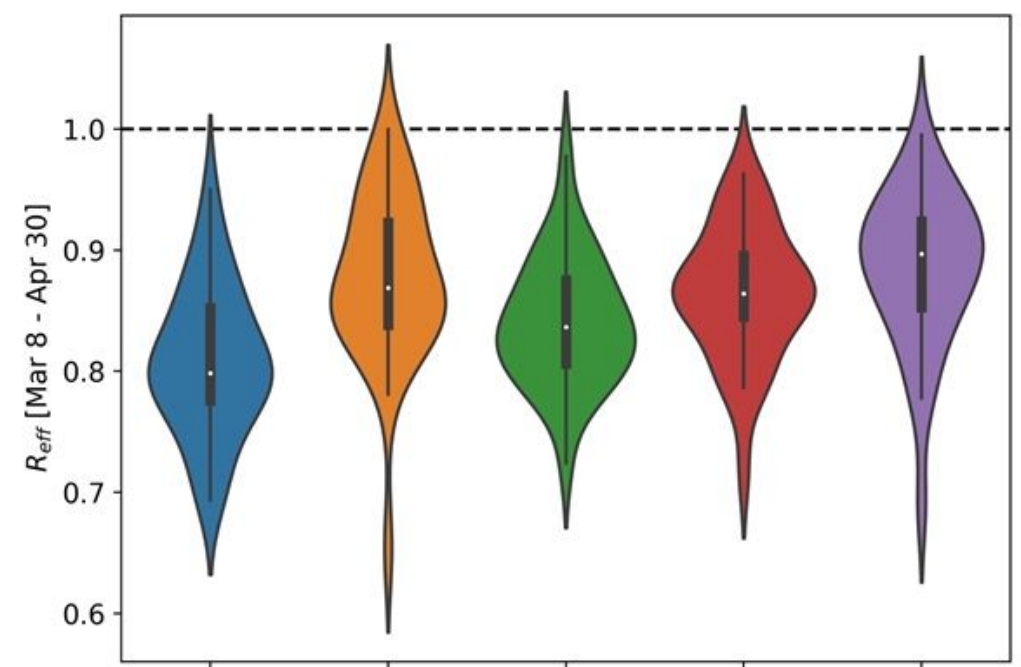

FNL Staggered PNLPrimary PNLPart-Rota PNL Full PNL scenario

\section{Figure 3}

Estimated values of the mean effective reproduction number between March 8, 2021 and April 19, 2021 under the current epidemic trajectory and with different assumption of reopening schools from March 8, 2011. We show the point estimate and the uncertainty range for each scenario.

\section{Supplementary Files}

This is a list of supplementary files associated with this preprint. Click to download.

- SupplementarymaterialNatCommssubmission.pdf 